\title{
Pengembangan Bahan Ajar Stuktur Aljabar dengan Penemuan Terbimbing untuk Meningkatkan Kemampuan Abstraksi dan Menulis Pembuktian Matematis
}

\author{
Ratih Kusumawati $^{1 *}$, Prihadi Kurniawan ${ }^{2}$ \\ ${ }^{1}$ Universitas Ivet, ${ }^{2}$ UIN Walisongo Semarang \\ *kusumaratih91@gmail.com
}

Diterima: Nopember 2019. Disetujui: Desember 2019. Dipublikasikan: Januari 2020

\begin{abstract}
ABSTRAK
Penelitian ini bertujuan untuk mendapatkan bahan ajar dengan penemuan terbimbing yang sarat dengan konstruksi pemahaman struktur aljabar dengan pertanyaan-pertanyaan penggiring dan strategi bantuan sebelum diberikannya definisi atau dibuktikannya teorema. Penelitian ini merupakan penelitian pengembangan dengan menggunakan model pengembangan ADDIE (Analysis, Design, Development, Implementation, Evaluation). Setelah melalui tahap analisis, desain, dan pengembangan, bahan ajar yang telah divalidasi, direvisi, dan dinyatakan layak untuk diimplementasikan kemudian digunakan sebagai sumber perkuliahan dalam tahap implementasi. Pada tahap ini, peneliti mengobservasi penggunaan bahan ajar dan mahasiswa melaksanakan evaluasi sesuai dengan masalah-masalah yang telah ditentukan dalam bahan ajar. Peneliti mengambil data tentang respon dosen dan mahasiswa tentang bahan ajar dan kemampuan abstraksi serta menulis bukti mahasiswa. Terakhir, pada tahap evaluasi, peneliti menganalisis hasil observasi di tahap sebelumnya. Data yang dikumpulkan adalah data hasil observasi penggunaan bahan ajar, angket kepraktisan bahan ajar, dan hasil tes untuk menilai kemampuan abstraksi dan menulis pembuktian matematis. Analisis yang dilakukan meliputi analisis validitas bahan ajar, analisis kepraktisan bahan ajar, serta analisis keefektifan bahan ajar terhadap kemampuan berpikir abstrak dan menulis pembuktian matematis mahasiswa. Pada tahap akhir penelitian, peneliti melakukan peninjauan kembali untuk perbaikan berdasarkan hasil analisis. Hasil yang diperoleh dalam penelitian penggembangan ini adalah bahan ajar yang dikembangkan valid, praktis, dan efektif dalam hal meningkatkan kemampuan berpikir abstak dan menulis bukti mahasiswa.
\end{abstract}

Kata kunci: bahan ajar, struktur aljabar, penemuan terbimbing, kemampuan abstraksi, pembuktian matematis.

\section{ABSTRACT}

This study aims to obtain teaching materials with guided discoveries that are laden with constructs of understanding algebraic structure with herding questions and assistance strategies before giving a definition or proofing theorem. This research is a development study using the ADDIE development model (Analysis, Design, Development, Implementation, Evaluation). After going through the stages of analysis, design, and development, teaching materials that have been validated, revised, and declared feasible to be implemented are then used as a source of lectures in the implementation phase. At this stage, researchers observe the use of teaching materials and students carry out evaluations in accordance with the problems that have been determined in teaching materials. Researchers took data about the responses of lecturers and students about teaching materials and abilities of abstraction and wrote student evidence. Finally, at the evaluation stage, researchers analyzed the results of observations in the previous stage. The data collected is data from observations of the use of teaching materials, questionnaire practicality of teaching materials, and test results to assess the ability of abstraction and write mathematical proofs. The analysis included an analysis of the validity of teaching materials, an analysis of the practicality of teaching materials, and an analysis of the effectiveness of teaching materials on the ability to think abstractly and write mathematical proofs of students. In the final stage of the study, the researcher conducts a review for improvement based on the results of the analysis. The results obtained in this research development are teaching materials that are developed valid, practical, and effective in terms of improving the ability to think abstract and write student evidence.

Keywords: text book, abstract algebra, guided discovery, ability of abstraction, ability on proof writing.

How to Cite: Kusumawati, R. \& Kurniawan, P. (2017). Pengembangan Bahan Ajar Stuktur Aljabar dengan Penemuan Terbimbing untuk Meningkatkan Kemampuan Abstraksi dan Menulis Pembuktian Matematis. Journal of Medives: Journal of Mathematics Education IKIP Veteran Semarang, 4(1), 197-204. 


\section{PENDAHULUAN}

Mata kuliah struktur aljabar merupakan salah satu materi matematika aksiomatik yang sarat dengan definisi dan teorema. Mempelajari struktur aljabar sangat membantu menanamkan tata nalar yang logis, sehingga bermanfaat dalam mempelajari bagian matematika aksiomatik yang lain (Isnarto, 2008). Karakteristik dari struktur aljabar adalah memiliki struktur deduktif aksiomatis yang ketat dan runtut, sarat dengan konsep yang abstrak, baik pada definisi maupun teorema (Panggabean, 2015). Menurut pengamatan peneliti sebagai dosen pengampu mata kuliah struktur aljabar, mata kuliah ini menjadi materi yang sulit dipahami oleh mahasiswa. Hal ini terlihat dari hasil pekerjaan rutin ujian mahasiswa yang rata-rata nilainya tidak mencapai separuh dari skor maksimal. Dubinsky, dkk. (1994) juga menjelaskan bahwa sebagian besar siswa di kelas aljabar abstrak memiliki kesulitan besar untuk memahami apa yang dijelaskan oleh dosen. Arnawa (2010) mengutarakan hal yang sama, bahwa aljabar abstrak merupakan mata kuliah yang sulit untuk dipelajari dan sulit untuk diajarkan. Kesulitan ini muncul tidak hanya karena materi perkuliahan yang terbilang abstrak, tetapi juga karena mahasiswa dituntut memiliki kemampuan membuktikan secara deduktif dan aksiomatik yang baik. Kemampuan dalam mengabstraksikan konsep dan membangun bukti inilah yang menjadi kendala utama mahasiswa.

Hasil wawancara dengan beberapa mahasiswa menunjukkan bahwa kendala lain yang dialami mahasiswa adalah mereka tidak memiliki sumber belajar yang cukup. Kebanyakan bahan ajar adalah buku teks berbahasa Inggris yang cukup sulit dipahami oleh sebagian besar mahasiswa. Selain itu, beberapa bahan ajar berbahasa Indonesia yang ada selama ini terlalu berkutat pada teori dan tidak fokus pada langkah-langkah proses konstruksi pengetahuan mahasiswa dalam membuktikan suatu teorema. Padahal hasil observasi menunjukkan sebagian besar mahasiswa tidak mempunyai kemampuan abstraksi yang cukup, sehingga bahkan definisi-definisi awal tidak dapat mereka pahami. Selain itu, mahasiswa dipaksa untuk mendalami beberapa teorema di saat mereka belum memahami benar definisi yang berkaitan.

Berawal dari permasalahan ini, peneliti memandang perlu adanya sumber belajar yang dapat mengembangkan kemampuan abstraksi dan kemampuan bernalar secara deduktif yang dapat dikembangkan melalui aktivitas menulis bukti matematis (Cyr, 2011). Kemampuan abstraksi menjadi salah satu kemampuan yang menjadi tujuan diajarkannya konsep-konsep matematika. Indikator dari kemampuan abstraksi matematis menurut Nurhasanah (2010) meliputi merepresentasikan masalah ke dalam bahasa dan simbol-simbol matematika, pengidentifikasian dan perumusan masalah, pembentukan objek matematika lebih lanjut, pembentukan konsep matematika terkait konsep yang lain, dan proses memanipulasi simbol.

Weber (dalaam Van Spronsen, 2008) menyatakan menulis bukti matematis adalah tugas matematika di 
mana pembelajar disediakan sejumlah informasi awal seperti asumsi, aksioma, atau definisi, dan diminta untuk menerapkan aturan menarik kesimpulan (misalnya mengingat fakta yang ditetapkan sebelumnya, menggunakan teorema) sampai kesimpulan yang dikehendaki diperoleh. NCTM (2000) mengungkapkan bahwa indikator kemampuan pembuktian matematis meliputi (1) mengenal penalaran dan pembuktian sebagai aspek-aspek fundamental matematika, (2) membuat konjektur dan memeriksa kebenaran dari konjektur itu, (3) mengembangkan dan mengevaluasi argumen dan pembuktian matematis, dan (4) memilih dan menggunakan bermacam-macam jenis penalaran dan metode pembuktian.

Aktivitas menulis pembuktian matematis dapat dikembangkan melalui penggunaan bahan ajar dan metode pembelajaran yang tepat. Beberapa penelitian pengembangan bahan ajar untuk mata kuliah struktur aljabar telah dilakukan. Dubinsky dan Leron (1994) telah membuat buku ajar aljabar abstrak berbantuan ISETL, suatu program aplikasi komputer yang digunakan untuk membantu mahasiswa mengonstruksi ide-ide matematika. Kemudian dengan ide yang sama, Nurlaelah dan Usdiyana (2005) membuat suatu inovasi pembelajaran struktur aljabar dengan menerapkan program ISETL yang bertujuan membentuk konstruksi mental mahasiswa tanpa adanya pengembangan bahan ajar tertentu. Mahasiswa menjadi lebih aktif, baik secara mental dan fisik, dalam mengikuti perkuliahan. Tetapi ada beberapa hambatan berkaitan dengan penggunaan aplikasi komputer dalam mengkonstruksi pemahaman mahasiswa, salah satunya adalah beberapa mahasiswa tidak tahu banyak tentang program komputer ISETL, sehingga proses di laboratorium berlangsung lambat. Yuniati (2012) mengembangkan bahan ajar struktur aljabar berbasis tugas resitasi, namun hanya dilakukan hingga uji coba terbatas dan tidak dilanjutkan untuk uji coba lapangan. Andari dan Lusiana (2016) telah mengembangkan bahan ajar struktur aljabar dengan menerapkan model pembelajaran snowball throwing berbasis tugas terstruktur yang mendapatkan respon positif dari mahasiswa. Fadillah (2016) dan Jamilah (2017) mengembangakan bahan ajar dengan fokus pada peningkatan kemampuan pembuktian matematis mahasiswa, namun tidak dengan mengimplementasi model pembelajaran tertentu.

Isnarto, dkk. (2014) telah meneliti bahwa penerapan Guided Discovery Learning (Pembelajaran Penemuan Terbimbing) melalui Motivation to Reasoning and Proving Tasks (Motivasi pada Tugas-Tugas Penalaran dan Pembuktian) (GDL-MRP Tasks) pada pembelajaran aljabar abstrak berpengaruh positif pada kemampuan mahasiswa dalam mengonstruksi bukti, memahami bukti, dan berpikir kritisnya. Melalui hasil-hasil penelitian tersebut, kemudian dapat dikembangkan penelitian lanjutan berupa penelitian pengembangan bahan ajar yang dikolaborasikan dengan penerapan model pembelajaran inovatif. Model Guided Discovery Learning dipilih agar bahan ajar yang dikembangkan dapat memuat tugastugas penemuan untuk membimbing 
mahasiswa untuk terlibat aktif dan konstruktif (Alfieri, dkk., 2011). Harapannya bahan ajar ini dapat dijadikan sebagai acuan sumber belajar utama yang dapat lebih efektif membantu mahasiswa dalam mengabstraksikan konsep-konsep aljabar abstrak serta menuliskan bukti-bukti yang diperlukan dalam pengembangan kemampuan penalaran deduktifnya secara lebih aktif dan optimal melalui serangkaian tugas-tugas penemuan.

\section{METODE PENELITIAN}

Penelitian ini merupakan penelitian pengembangan dengan menggunakan model pengembangan ADDIE (Analysis, Design, Development, Implementation, Evaluation) yang merupakan suatu kerangka desain instruksional sistem yang biasa digunakan pada aktivitas pengembangan kurikulum (Andari dan Lusiana, 2016). Fase-fase pengembangan yang dilakukan adalah sebagai berikut.

Analisis

Peneliti mengidentifikasi dan merumuskan masalah. Peneliti menganalisis perlunya mengembangkan bahan ajar berdasarkan beberapa syarat kelayakan pengembangan meliputi analisis kebutuhan, analisis kurikulum, dan analisis karakter mahasiswa. Hasil analisis yang meliputi analisis perlunya mengembangkan bahan ajar, analisis kebutuhan, analisis kurikulum, analisis karakter mahasiswa, dan analisis metode pembelajaran telah diuraikan dalam latar belakang. Tahap ini diakhiri dengan persiapan tahap desain bahan ajar struktur aljabar dengan penemuan terbimbing.
Desain

Pada fase ini, peneliti membuat rancangan bahan ajar struktur aljabar dengan penemuan terbimbing dengan memperhatikan kemampuan abstraksi dan menulis pembuktian mahasiswa berdasarkan hasil analisis di fase sebelumnya. Peneliti kemudian menentukan unsur-unsur yang diperlukan dalam bahan ajar sehingga kerangka dan peta kebutuhan bahan ajar dapat ditentukan. Unsur utama yang disematkan dalam bahan ajar ini adalah panduan atau komponen penemuan terbimbing untuk mahasiswa. Panduan ini berisikan langkah-langkah yang diberikan kepada mahasiswa sehingga mereka dapat merumuskan masalah, memproses dan menganalisis ide-ide yang dimiliki, memperkirakan solusi, dan akhirnya menemukan apa yang mereka butuhkan. Melalui panduan-panduan ini mahasiswa dilatih untuk bekerja secara mandiri namun tetap berpedoman pada arahanarahan dasar dari dosen. Fase ini dilanjutkan dengan dengan membuat instrumen validitas bahan ajar. Terakhir sumber buku dan rujukan utama yang akan digunakan dalam mengembangkan bahan ajar diadakan.

\section{Pengembangan}

Peneliti merealisasikan desain yang telah dibuat pada fase desain. Pada fase ini, bahan ajar dibuat sesuai dengan rancangan dan kemudian divalidasi dengan menggunakan instrumen yang telah dibuat. Hasil validasi akan meliputi penilaian aspek kevalidan bahan ajar dan analisisnya.

\section{Implementasi \\ Implementasi dilakukan secara terbatas pada mahasiswa yang meng-}


ambil mata kuliah struktur aljabar. Bahan ajar yang telah divalidasi dan dinyatakan layak untuk diimplementasikan kemudian digunakan sebagai sumber perkuliahan. Pada fase implementasi, peneliti mengobservasi penggunaan bahan ajar dan mahasiswa melaksanakan evaluasi sesuai dengan masalah-masalah yang telah ditentukan dalam bahan ajar. Peneliti juga mengambil data tentang respon mahasiswa tentang bahan ajar untuk kemudian dianalisis apakah bahan ajar praktis dan efektif.

\section{Evaluasi}

Pada fase ini, peneliti menganalisis hasil observasi yang dilakukan pada fase implementasi. Analisis yang dilakukan meliputi analisis kepraktisan dan keefektifan bahan ajar terhadap kemampuan berpikir abstrak dan menulis bukti mahasiswa. Kemudian peneliti melakukan peninjauan kembali untuk perbaikan berdasarkan hasil analisis. Jika bahan ajar telah dinyatakan praktis dan efektif maka draft akhir bahan ajar telah selesai dan siap digunakan dalam uji coba skala yang lebih besar.
Penelitian ini dilakukan di Program Studi Pendidikan Matematika Universitas Ivet. Uji coba terbatas dilakukan kepada mahasiswa pendidikan matematika semester 4 tahun akademik 2018/2019. Teknik yang digunakan dalam pengumpulan data adalah metode observasi dan angket pada fase analisis, pengembangan, dan implementasi, serta metode tes pada fase evaluasi.

Bahan ajar dianggap baik apabila memenuhi kriteria-kriteria: valid, praktis, dan efektif. Dalam proses pengembangan bahan ajar, kriteria validitas ditinjau dari segi isi, materi, format, dan bahasa. Uji validitas dilakukan dengan menggunakan angket validitas ahli yang dianalisis secara deskriptif. Bahan ajar dikatakan valid apabila memperoleh nilai rata-rata minimal 4 dari skor maksimal 5. Kriteria kepraktisan ditinjau dari segi kemudahan penggunaan bahan ajar yang dinilai dengan menggunakan angket kepraktisan bahan ajar. Bahan ajar dikatakan praktis apabila mendapat skor minimal 3 dari skor maksimal 5. Sementara kriteria keefektifan ditinjau dari hasil uji coba

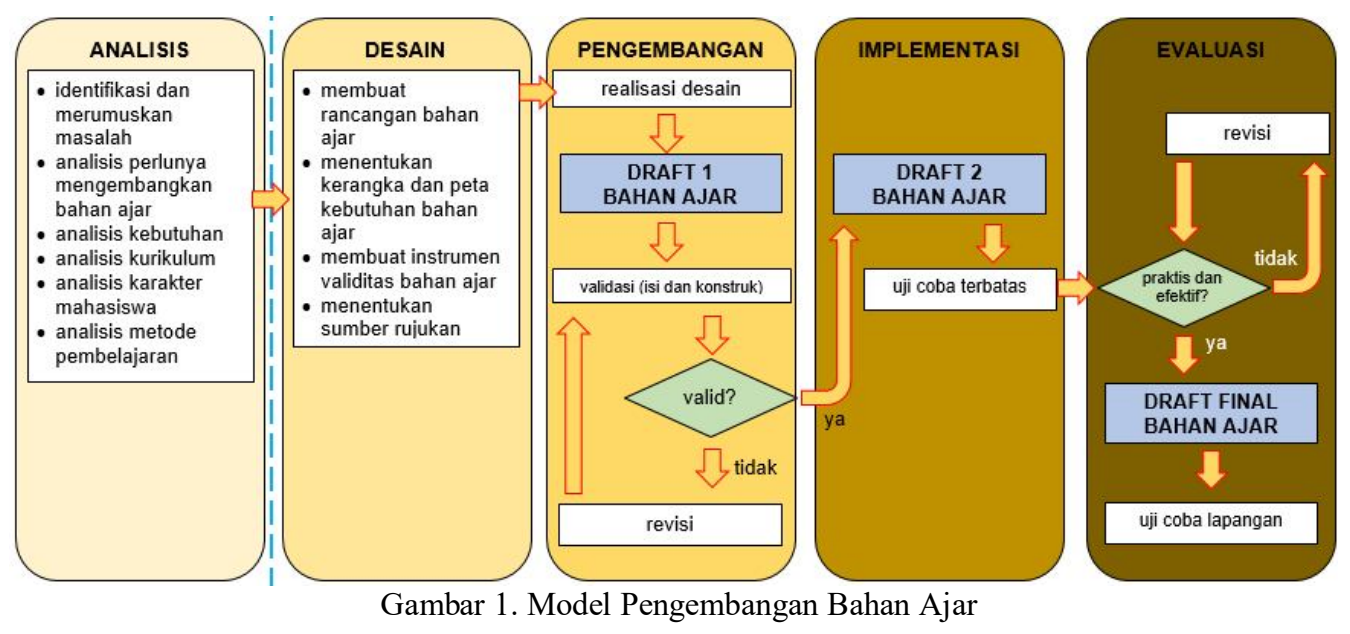


perangkat untuk mengukur tingkat kemampuan berpikir abstrak dan menulis bukti mahasiswa. Bahan ajar dinilai efektif apabila dengan adanya bahan ajar ini, kemampuan berpikir abstrak dan menulis bukti mahasiswa dapat meningkat secara signifikan ditunjukkan dengan menggunakan uji ngain.

\section{HASIL DAN PEMBAHASAN}

\section{Pengembangan}

Dalam fase pengembangan awal telah dilakukan realisasi desain berdasarkan analisis di fase sebelumnya. Realisasi desain meliputi: pengaturan urutan materi perkuliahan, menentukan tujuan pembelajaran di setiap bab, penulisan materi bahan ajar, menyematkan panduan-panduan untuk mahasiswa yang terintegrasi dalam bahan ajar, pemilihan soal-soal latihan yang disematkan di akhir bab, kemudian diakhiri dengan mencantumkan kelengkapan bahan ajar yang meliputi: daftar isi, daftar pustaka, indeks, sampul, dan kata pengantar. Gambar 2 dan 3 merupakan gambaran umum bahan ajar hasil realisasi desain.

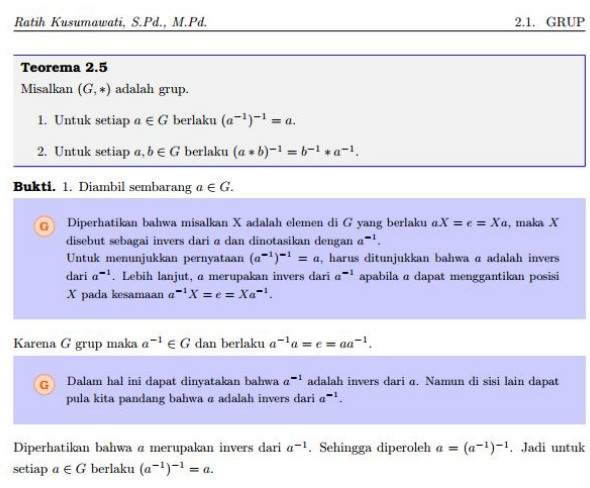

Gambar 2. Desain Materi Bahan Ajar

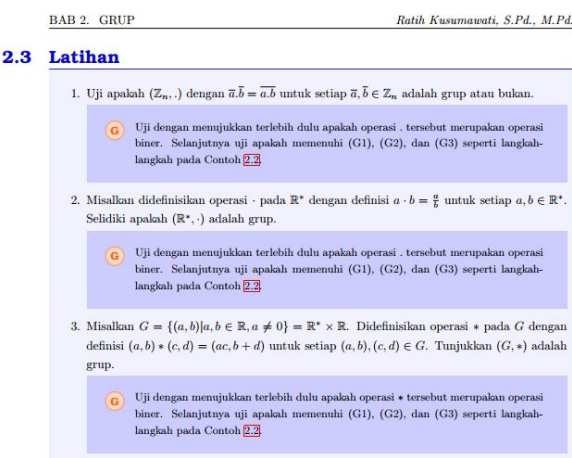

Gambar 3. Desain Latihan di Akhir Bab

Setelah draft bahan ajar pertama selesai, dilakukan uji validitas ahli. Hasil uji validitas ditunjukkan pada Tabel 1.

Tabel 1. Hasil uji validitas

\begin{tabular}{lccc}
\hline Aspek Validasi & Val 1 & Val 2 & Rata-Rata \\
\hline Materi & 4,1 & 4,6 & 4,3 \\
Bahasa & 4,0 & 4,5 & 4,2 \\
Tampilan & 4,2 & 4,4 & 4,3 \\
Metodologi & 4,1 & 4,7 & 4,4 \\
\hline
\end{tabular}

Rata-rata hasil validasi adalah 4,35 dengan rata-rata aspek paling tinggi adalah aspek metodologi. Validator 1 memberikan saran perbaikan dalam uraian materi bab 1 dan bab 5 untuk dapat menambahkan panduan strategi pemecahan masalah untuk mahasiswa yang termuat di contoh soal yang disajikan. Validator 2 memberikan saran perbaikan pada Contoh 5.1 pada bahan ajar agar menuliskan pembahasan lebih detail. Disimpulkan bahwa berdasarkan penilaian validator draft modul layak digunakan untuk uji coba. Peneliti selanjutnya melakukan revisi sesuai dengan hasil validasi sehingga diperoleh bahan ajar yang siap digunakan pada tahap implementasi. 


\section{Implementasi}

Tahap implementasi dilaksana-kan pada mahasiswa pendidikan matematika semester 4. Mahasiswa yang diikut sertakan dalam tahap ini sejumlah 12 orang. Implementasi dilaksanakan dalam waktu satu bulan (empat minggu). Minggu pertama mahasiswa diberikan pretest tentang pemahaman dasar grup dan sifat-sifat anggotanya yang difokuskan dalam kemampuan berpikir abstrak dan menulis pembuktian matematis. Kemudian minggu kedua hingga keempat, mahasiswa dibekali materi dengan bahan ajar yang telah dikembangkan, dan digunakan sebagai sumber perkuliahan. Pada minggu keempat mahasiswa diberikan posttest yang menilai kemampuan berpikir abstrak dan menulis pembuktian matematis pada materi yang sama. Terakhir mahasiswa diminta untuk mengisi lembar respon di akhir tahap implementasi.

Selama tahap implementasi, peneliti mengobservasi bagaimana mahasiswa mengerjakan soal-soal latihan dengan menggunakan panduan yang telah disediakan dalam bahan ajar. Peneliti memperhatikan bagaimana mahasiswa berpikir abstrak dan menuangkannya dalam suatu kalimat pembuktian yang tepat. Melalui hasil observasi ini, peneliti dapat memberikan gambaran secara kualitatif bagaimana kemampuan menulis bukti mahasiswa dapat berkembang.

\section{Evaluasi}

Tahap evaluasi yang dilaksanakan adalah sebagai berikut. Berdasarkan data hasil pretest dan posttest yang menilai kemampuan berpikir abstrak dan menulis pembuktian matematis diperoleh nilai $g$ sebesar 0,6 yang termasuk dalam kategori sedang. Berdasarkan data hasil posttest diperoleh bahwa rata-rata nilai adalah 73. Berdasarkan hasil ini dapat disimpulkan bahan ajar efektif untuk meningkatkan kemampuan berpikir abstrak dan menulis pembuktian matematis. Lebih lanjut, berdasarkan hasil respon mahasiswa diperoleh bahwa skor akhir yang diperoleh adalah $87 \%$ yang berarti respon mahasiswa terkait bahan ajar adalah positif, sehingga bahan ajar termasuk dalam kategori praktis. Sehingga dapat disimpulkan bahwa bahan ajar struktur aljabar dengan penemuan terbimbing dapat meningkatkan kemampuan berpikir abstrak dan menulis pembuktian matematis.

\section{PENUTUP}

Berdasarkan pertanyaan penelitian dan hasil penelitian yang telah diuraikan, diperoleh kesimpulan sebagai berikut. Pertama, dihasilkan prototype pengembangan bahan ajar. Kedua, dihasilkan bahan ajar stuktur aljabar dengan penemuan terbimbing untuk meningkatkan kemampuan abstraksi dan menulis pembuktian matematis yang memenuhi kriteria valid (skor 3,4), praktis $(87 \%$ ), dan efektif.

Berdasarkan kesimpulan yang dikemukakan tersebut, maka beberapa saran yang perlu dipertimbangkan untuk peningkatan kualitas pembelajaran matematika sekolah sebagai berikut. Dosen disarankan untuk memanfaatkan bahan ajar yang dikembangkan sebagai salah satu bahan ajar dalam perkuliahan Struktur Aljabar. 


\section{DAFTAR PUSTAKA}

Alfieri, L., Brooks, P. J., Aldrich, N. J., \& Tenenbaum, H. R. (2011). Does discovery-based instruction enhance learning?. Journal of educational psychology, 103(1), 1.

Andari, T. \& Lusiana, R. (2016). Pengembangan Perangkat Pembelajaran Dengan Menggunakan Model Pembelajaran Snowball Throwing Berbasis Tugas Terstruktur Pada Mata Kuliah Struktur Aljabar I. Jurnal Edukasi Mat. dan Sains, 2(1).

Arnawa, I. M. (2010). Mengembangkan kemampuan mahasiswa dalam memvalidasi bukti pada aljabar abstrak melalui pembelajaran berdasarkan teori APOS. Jurnal matematika dan Sains, 14(2), 6268.

Cyr, S. (2011). Development of beginning skills in proving and proof writing by elementary school students. In Proceedings of the Seventh Congress of the European Society for Research in Mathematics Education.

Dubinsky, E., Dautermann, J., Leron, U., \& Zazkis, R. (1994). On learning fundamental concepts of group theory. Educational studies in Mathematics, 27(3), 267-305.

Fadillah, S., \& Jamilah, J. (2016). Pengembangan Bahan Ajar Struktur Aljabar untuk Meningkatkan Kemampuan Pembuktian Matematis Mahasiswa. Cakrawala Pendidikan, (1), 80660.

Isnarto. (2008) Buku Ajar Pengantar Struktur Aljabar 1. Semarang: UNNES.
Isnarto, W., Suryadi, D., \& Dahlan, A. J. (2014). Students' proof ability: Exploratory studies of abstract algebra course. International Journal of Education and Research, 2(6), 215-228.

Jamilah, J., \& Fadillah, S. (2017). Penggunaan Bahan Ajar Struktur Aljabar untuk Meningkatkan Kemampuan Pembuktian Matematis pada Mahasiswa IKIP PGRI Pontianak. Jurnal Pendidikan Matematika dan IPA, 8(2), 60-69.

National Council of Teachers of Mathematics (NCTM). (2000). Curriculum and Evaluation Standards for School Mathematics. Reston, VA: National Council of Teachers of Mathematics.

Nurhasanah, F. (2010). Abstraksi Siswa SMP dalam Belajar Geometri melalui Penerapan Model Van Hiele dan Geomeer's Sketchpad. Tesis Magister SPs UPI Bandung: Tidak diterbitkan.

Panggabean, E. M. (2015). Pengembangan Bahan Ajar Dengan Strategi React Pada Mata Kuliah Struktur Aljabar I Di FKIP UMSU. EduTech: Jurnal Ilmu Pendidikan dan Ilmu Sosial, 1(01).

Van Spronsen, H. D. (2008) Proof Processes of Novice Mathematics Proof Writers, Disertasi pada The University of Montana Missoula: Tidak dipublikasikan. 